\title{
Quality of nursing services and inpatient satisfaction
}

\author{
Chairun Nasirin ${ }^{\mathrm{a}^{*}}$ and Haerani Asrina ${ }^{\mathrm{a}}$
}

\begin{tabular}{l}
$\frac{{ }^{a} \text { College of Health Sciences (STIK }}{\text { C H R O N I C L E }}$ \\
\hline Article history: \\
Received: February 15, 2020 \\
Received in revised format: \\
March 162020 \\
Accepted: March 16, 2020 \\
Available online: \\
March 16, 2020 \\
\hline Keywords: \\
Service quality \\
Nursing practices \\
Patient satisfaction \\
Health center
\end{tabular}

\section{Introduction}

Indonesia with its vision 'Healthy Indonesia 2015' illustrates that future Indonesians whose inhabitants live in the environment and with healthy living behaviors, have the ability to reach quality health services fairly and equally, and have the highest health status. Health development is an effort aimed at increasing awareness, willingness and ability to live a healthy life for everyone in order to realize the highest degree of public health. In order to achieve these goals, health development is carried out in a directed, continuous and realistic manner in accordance with its stages (Depkes RI, 2009). Moreover, Law No. $36 / 2009$ concerning health chapter 1 Article 1 health is associated with a healthy condition, physically, mentally, spiritually and socially that enables everyone to live productively socially and economically. Law No. 38 of 2014 concerning Nursing chapter 1 Article 1 nursing service is a form of professional service that is an integral part of health services based on nursing knowledge shown to individuals, families, groups, and the community, both healthy and sick. Nurses in carrying out nursing practices provide nursing services in accordance with the code of ethics, nursing service standards, professional standards, operational procedure standards, and statutory provisions (Kozier, 2008; American Nurses Association, 2001; Fowler, 2008; World Health Organization, 2009). The law on health is certainly inseparable from health services, one of which is the health center. Health center is a community health center that provides health services to the community in its work area, both through individual health efforts and public health efforts aimed at improving community health status (Connor et al., 2007; Morris et al., 2008). In Indonesia, health center working area mostly covers one sub-district or part of a sub-district. To achieve quality services, the health center must provide services in accordance with nursing service standards (Bolton \& Goodenough, 2003; Lee \& Yom, 2007). Nursing service standards serve as guidelines for nurses in providing services to individuals, families and communities in the health center so that quality services are created in accordance with patient expectations (see also, Tseng, 2009; Zarei et al., 2012; Teng et al., 2009). The goal of quality nursing care is to provide patient satisfaction. Patient satisfaction with nursing services will be felt if the expected nursing services are comparable or more than the

* Corresponding author

E-mail address: chairun.nasirin@stikes-mataram.ac.id (C. Nasirin)

(C) 2020 by the authors; licensee Growing Science, Canada doi: $10.5267 /$ j.msl.2020.3.020 
performance of nurses. If patients are satisfied with nursing services then when needed services will be utilized again. Patient satisfaction with nursing services is certainly inseparable from the important role of nurses (Scardina, 1994; Tzeng et al., 2002).

As a nurse to improve the quality of health services, among others, the role of nurses as care giver where nurses are responsible for providing nursing services from simple to complex to individuals, families and communities directly or indirectly becomes important. Families are considered a group of people who live in one house and are responsible for deciding the best service for sick family members. The West Lombok Regency Government through the West Lombok Health Service in providing the best service to the community is strengthened by health regulation No. 231 of 2004 concerning the Implementation of Inpatient Health Centers. The main activity of Gunung Sari Health center is health promotion, this activity is carried out to provide health education for the community so that they can prevent infectious diseases. Accordingly, this study aims to examine the effect of the quality of nursing services to patient satisfaction at the Gunung Sari health center in West Lombok Regency.

\section{Literature Review}

\subsection{Services and Satisfaction for Patients}

Service is an important thing that cannot be separated from the existence of facilities or infrastructure that supports these services. Services are also carried out to meet personal needs so that service providers could provide services properly. Good service is performed to provide satisfaction to patients as recipients of services so that one day, if needed, services will be used again. This is reinforced by Muninjaya's (2012) statement that services are activities carried out by health service provider institutions that are intentionally sold to provide satisfaction to the wearer, for example services for outpatient treatment or inpatient care at health center or hospitals. Asmuji (2012) explains that service is an act when someone or a group offers to a group/others something that is basically intangible and the production is related or not related to the physical product. Health services are activities carried out by health service provider institutions that offer something that is essentially intangible to groups/people with the aim of providing satisfaction to the user.

\subsection{Quality of service}

Quality is the level of perfection of the appearance of something that is being observed based on established standards in order to adjust to customer desires, one of which is service quality. Quality of service is a very important thing that must be applied in nursing services at a health institution because this quality will provide a good perception of the services available at the health center (Goberna-Tricas et al., 2011). Satrianegara and Saleha (2009) stated that quality of service is the degree of perfection of health services in accordance with professional standards and the standards of resources available in hospitals and health centers in a reasonable, efficient and effective manner, and are given safely and satisfactorily according to norms, ethics, law and socio-cultural norms. This is strengthened by the statement of Asmuji (2012) about the quality of nursing services, stating that a condition that describes the level of perfection of the appearance of a nursing service provided comprehensively (bio-psycho-social-spiritual) to sick and healthy individuals based on standards (nursing process) predetermined to suit customer desires. Hence, the quality of service is the degree of perfection of the appearance of a nursing service that is provided comprehensively to individuals who are sick or healthy in accordance with professional standards and the standard of resources that are reasonably available at hospitals and health centers to be efficient and effective to adjust to the patients' wishes.

\subsection{Patient Satisfaction with Nursing Services}

Patient satisfaction with nursing services is determined by the suitability of services perceived by patients with patient expectations. This statement is supported by Nursalam (2014) that patient satisfaction is the result of an evaluation (comparison) of what is obtained with what is expected, not an attitude (liking something or disliking without a comparison element). Measurement of satisfaction using multiple items so as to be able to provide information that makes satisfied and dissatisfied. Asmuji (2012) stated that patients would feel satisfied if the service received were at least the same or more than expected. Thus, they will reuse the services they have received. This is the cheapest but the most effective marketing method. Meanwhile, according to Supriyanto and Ernawati (2010) patient satisfaction occurs when what the needs, desires, or what the patient hopes can be met. Patient satisfaction is a feeling of pleasure or satisfaction that the service received has met or exceeded the patient's expectations. Another opinion is also from Tjiptono (2009) who said that giving satisfaction means being able to understand the needs and desires of patients, friendly and polite in providing services, providing healing guarantees so that patients are confident in the treatment performed and do not differentiate patient status or position.

\section{Research Methods}

This study uses an analytic observational design with a cross sectional approach that aims to take measurements or observations at the same time (Hidayat, 2014). The object of this study was to perform the investigation on inpatients at the Gunung Sari Health center of West Lombok Regency. The sampling technique used in this study is accidental sampling, 
which is a sampling method that is done by coincidence. This means that anyone who happens to meet with a researcher can be used as a sample, if it is seen that the person who happened to be met is suitable as a source of data (Hidayat, 2014). The instrument used in this study was through the distribution of questionnaires that were delivered directly to inpatients at the Gunung Sari Health center of West Lombok Regency who were included as samples to determine the quality of service and patient satisfaction. In addition, interviews were conducted with one patient/family at the Gunung Sari Health center of West Lombok Regency to find out more about the services provided by nurses and the patient/family satisfaction.

In this study, the independent variable is the quality of nursing services at Gunung Sari Health center, West Lombok Regency and the dependent variable is patient satisfaction at Gunung Sari Health center, West Lombok Regency. The data collected was then tabulated and analyzed using the Chi-Squared test with the help of SPSS Version 22. Analysis of the data used in this study was Chi-Squared analysis with the help of SPSS version 22 with a significant level of 0.05 . Chi Square data analysis is used to estimate or evaluate the frequency being investigated or analyze the results of observations to find out whether there are significant relationships or differences in research using nominal data (Hidayat, 2014).

\section{Results and Discussion}

\subsection{Characteristics of Respondents}

Based on the results of the study the number of inpatient visits at the Gunung Sari Health was 173 people with 68 patients being respondents while 105 were non-respondents due to not entering as a criterion of respondents based on age, refusing as a respondent, and going home or moving house sick for less than three days. Of the 68 inpatients at the Gunung Sari Health center, the highest age category is the elderly with 56-65 years of age with 23 people with a percentage (33.8\%).

Table 1

Characteristics of Respondents

\begin{tabular}{llll}
\hline Characteristics & Range & Amount & Percentage \\
\hline Age & $12-16$ & 4 & 5.9 \\
& $17-25$ & 7 & 10.3 \\
& $26-35$ & 11 & 16.2 \\
& $36-45$ & 9 & 13.2 \\
& $46-55$ & 14 & 20.6 \\
\hline Education & $56-65$ & 23 & 33.8 \\
& Elementary school & 9 & 13.2 \\
& Middle school & 18 & 26.5 \\
& High School & 26 & 38.2 \\
\hline
\end{tabular}

Table 1 shows that of 68 inpatients at the Gunung Sari Health center, the highest level of education was elementary school with 19 people $(38.2 \%)$. This is because someone who has taken high school/vocational school can determine his/her own opinion in feeling the services provided by nurses at the health center. The lowest education level is elementary school with 9 people with percentages $(13.2 \%)$.

\subsection{Quality of nursing services and patient satisfaction}

Table 2 shows that of 68 inpatients at the Gunung Sari Health Center, there were 56 people who stated that the service was good, which was a percentage ( $82.2 \%$ ). This was confirmed by an interview with one of the inpatients, Mr. S.I (28 years) who suffered from dengue hemorrhagic fever (DHF) said that:

"The first time I was treated at the emergency room, the nurse immediately took care of the registration and observed my situation, because I was limp I was immediately paired with an IV and then I was advised to hospitalization.

Table 2

Distribution of respondents' responses based on the quality of nursing services

\begin{tabular}{|c|c|c|c|}
\hline No & Quality of Nursing Services & amount & Percentage $(\%)$ \\
\hline 1 & Good & 56 & 82.4 \\
\hline 2 & Moderate & 12 & 17.6 \\
\hline \multicolumn{2}{|c|}{ Total } & 68 & 100 \\
\hline
\end{tabular}

Based on observations, nurses are always there every hour of work in accordance with the shift schedule that has been posted at the nurse station and always work based on a predetermined SOP. A total of 12 people said the service was not good, namely the percentage (17.6\%). This shows that the quality of nursing services such as reliability and empathy at the Gunung Sari Health center is well implemented. 


\subsection{Patient satisfaction at the health center}

Table 3 shows that of 68 Inpatients at Gunung Sari Health center, there were 54 people said they were satisfied with the services provided by nurses with a percentage $(79.4 \%)$.

Table 3

Distribution of respondent responses based on patient satisfaction

\begin{tabular}{lllc}
\hline No & Patient Satisfaction & Amount & Percentage (\%) \\
\hline 1 & Satisfied & 54 & 79.4 \\
2 & Not satisfied & 14 & 20.6 \\
\hline \multicolumn{2}{c}{ Total } & 68 & 100 \\
\hline
\end{tabular}

This is based on an interview with one of the visitors who always come for medical treatment for themselves or to bring his sick family to the Gunung Sari Health Center, namely Mr. I. (43 years) said that:

"I am happy because nurses at Health center Gunung Sari are friendly, polite and smiling, at this center I am given the same service as other patients and are not discriminated against."

As many as 14 people said they were not satisfied with the services provided by nurses, namely the percentage (20.6\%). This is due to lack of equipment at the Health center which causes patients to be referred to the hospital. From the results, it shows that both patients and their families who come to the Gunung Sari health center are satisfied with the services provided by nurses. More closely, the results of research on the quality of nursing services to patient satisfaction at the Gunung Sari health center of 68 inpatients 56 people said the services provided by nurses were carried out well and 12 people said the service was felt not good. for more details can be seen in Table 4. It can be seen that out of 56 respondents who felt the services provided by nurses were good there were 54 respondents who said they were satisfied with the services provided by nurses with a percentage $(96.4 \%)$ and 2 people said they were not satisfied with the percentage $(3.6 \%)$. While respondents who said the services provided by nurses were not good as many as 12 people with a percentage (100\%) there were 12 respondents who were not satisfied with the services provided by nurses.

\section{Table 4}

Distribution of responses to the quality of nursing services to patient satisfaction

\begin{tabular}{|c|c|c|c|c|c|c|c|}
\hline \multirow{3}{*}{ No } & \multirow{3}{*}{$\begin{array}{l}\text { Quality of Nursing } \\
\text { Services }\end{array}$} & \multicolumn{4}{|c|}{ Patient Satisfaction } & \multirow{2}{*}{\multicolumn{2}{|c|}{ Total }} \\
\hline & & \multicolumn{2}{|c|}{ Satisfied } & \multicolumn{2}{|c|}{ Not satisfied } & & \\
\hline & & $\mathrm{F}$ & $\%$ & $\mathrm{~F}$ & $\%$ & $\mathrm{~F}$ & $\%$ \\
\hline 1 & Good & 54 & 96.4 & 2 & 3.6 & 56 & 100 \\
\hline 2 & Moderate & 0 & 0.0 & 12 & 100.0 & 12 & 100 \\
\hline \multicolumn{2}{|c|}{ Total } & 54 & 79.4 & 14 & 20.6 & 68 & 100 \\
\hline
\end{tabular}

This emphasizes that the better the services provided by nurses in providing nursing services, the more satisfied is felt by patients in receiving services provided by nurses. Therefore the quality of nursing services is very important to provide patient satisfaction. Based on the chi-square statistical test with the help of the SPSS v.22 program to look for the effect of the quality of nursing services on patient satisfaction p-value of $0.00<0.05$ means $\mathrm{H}_{\mathrm{o}}$ rejected and $\mathrm{H}_{\mathrm{a}}$ be accepted.

\section{Discussion}

The quality of nursing services is the level of perfection of a service provided by nurses to patients in accordance with established standards and adjusted to patient expectations where the quality of service referred to here is the quality of service reliability and empathy (American Nurses Association, 2009). Results of research have shown that the quality of nursing services provided by nurses at the Gunung Sari Health center is included in the good category where of 68 inpatients as many as 56 people with a percentage $(82.4 \%)$ said that the services provided by nurses were good. This is consistent with the opinion of Asmuji (2012) that reliability of services is the ability to provide appropriate and trusted services. Reliable service is consistent and competent service. This opinion is supported by Muninjaya (2012) that reliability is the ability to provide services in a timely and accurate manner as offered by Health center. Tribowo (2013) stated that good service is a service that is given reliably, precisely and accurately, is friendly and understands the patient's wishes. Supriyanto and Ernawati (2010) about the quality of empathy services stated that caring means being easily contacted and always paying attention to patients. For example, it is done by paying attention to patient complaints as individual and social beings (family and community). This opinion is supported by Asmuji's Statement (2012) that good service means listening to patient complaints, greeting patients, and other concerns which of course are limited to the therapeutic relationship of the nurse-patient. Patient satisfaction is the result of comparison of what is obtained with what is expected and needed. Patients will feel satisfied if the service received is at least the same or more than expected (see also, Haas et al., 2000). This is in accordance with Nursalam (2014) who states that patient satisfaction is an evaluation (comparison) of what is obtained with what is expected, not an attitude (liking something or disliking without a comparison element). This statement is supported by the opinion of Supranto (2011) 
that satisfaction as the level of one's feelings after comparing the perceived performance with expectations. If the performance is below expectations, the patient will be very disappointed, if the performance is as expected, the patient will be satisfied and if the performance exceeds expectations, the patient will feel very satisfied.

The results show that patient satisfaction with the services provided by nurses in the inpatient rooms of the Gunung Sari Health Center, as many as 54 people said they were satisfied with the services provided by nurses with a percentage (79.4\%). This is in accordance with the opinion of Supriyanto and Ernawati (2010) which states that satisfying means providing services individually with full attention and according to the needs or expectations of patients. For example, nurses want to listen to complaints and help resolve them, nurses do not distinguish patient status and are indifferent to the patient's condition and are easily contacted when patients need help. Tjiptono (2009) stated that giving satisfaction means being able to understand the needs and desires of patients, friendly and polite in providing services, providing healing guarantees so that patients are confident in the treatment performed and do not differentiate patient status or position. Similar opinion is also supported by Nursalam (2014) Nurses who are responsive in providing services will cause patients to feel satisfied with the service felt. where rapid response is meant by the readiness of nurses in providing services to patients both direct services or only provide information quickly and precisely when patients need it. The Chi-Square test with SPSS v.22 revealed that there is a significant influence between the quality of nursing services on patient satisfaction with p-value (0.00) with a significant level of $5 \%$ $(0.05)$. Of the 56 respondents who felt the services provided by nurses were good there were 54 respondents said they were satisfied with the services provided by nurses with a percentage $(96.4 \%)$ and 2 people said they were not satisfied with the percentage (3.6\%). While respondents who said the services provided by nurses were not good as many as 12 people there were 12 respondents who were not satisfied with the services provided by nurses. Muninjaya (2012) states that the goal of improving the quality of nursing services was to create patient satisfaction. So the better the quality of services provided by nurses to patients, the more satisfied the services felt by patients. A similar study was also conducted by Adhytyo and Mulyaningsih (2013) with the results of the study found that there was a significant relationship between the quality variables of nursing services namely physical evidence, reliability, responsiveness, empathy and guarantee with patient satisfaction at the with p-value of 0.000 .

\section{Conclusions}

The quality of nursing services is the level of perfection of nursing services provided by nurses to patients in accordance with established standards and aims to provide satisfaction for patients. One of the quality of nursing services in question is reliability and empathy. Based on the nursing services provided by nurses to patients at the Gunung Sari region West Lombok Health Center there were 56 people saying the service was good with a percentage $(82.2 \%)$. Patient satisfaction with the services has shown that at the Gunung Sari region West Lombok Health Center there were 54 people said they were satisfied with the services provided by nurses with a percentage (79.4\%). The importance of the quality of nursing services is certainly inseparable from the reliability and empathy of a health institution such as the Health center. Gunung Sari is one of the Health center located in the Gunung Sari region which is included in the good category where patients are satisfied with the services provided by nurses at the Health center. Based on the research results of Gunung Sari Health Center is one of the Health Centers located in the Gunung Sari region which is included in both categories, this can be seen from the need for regular evaluations to minimize the number of dissatisfaction with patients so that reliability and empathy can take precedence. Knowledge and skills of nurses also need to be considered so that the basic human needs (bio-psycho-socio-spiritual) in patients can be met. On the other hand this research can also be referred to by other researchers in an effort to complement the limitations of this study by taking into account other variables of the quality of nursing services such as quick assumptions, tangible manifestations and guarantees.

\section{References}

Adhytyo, D. R. (2013). Reliabilitas Mempengaruhi Kepuasan Pasien Terhadap Pelayanan Kesehatan Di Salah Satu Puskesmas Kabupaten Ngawi. Gaster: Jurnal Kesehatan, 10(2), 22-32.

American Nurses Association. (2001). Code of ethics for nurses with interpretive statements. Nursesbooks. org.

Asmuji. (2012). Manajemen Keperawatan Konsep dan Aplikasi. Jogjakarta: Ar-ruzz Media

Bolton, L. B., \& Goodenough, A. (2003). A magnet nursing service approach to nursing's role in quality improvement. Nursing Administration Quarterly, 27(4), 344-354.

Connor, A., Rainer, L. P., Simcox, J. B., \& Thomisee, K. (2007). Increasing the delivery of health care services to migrant farm worker families through a community partnership model. Public Health Nursing, 24(4), 355-360.

DepKes, R. I. (2009). Sistem Kesehatan Nasional bentuk dan cara penyelenggaraan pembangunan kesehatan.

Fowler, M. D. M. (2008). Guide to the code of ethics for nurses: Interpretation and application. Nursesbooks. org.

Goberna-Tricas, J., Banús-Giménez, M. R., Palacio-Tauste, A., \& Linares-Sancho, S. (2011). Satisfaction with pregnancy and birth services: the quality of maternity care services as experienced by women. Midwifery, 27(6), e231-e237.

Haas, J. S., Cook, E. F., Puopolo, A. L., Burstin, H. R., Cleary, P. D., \& Brennan, T. A. (2000). Is the professional satisfaction of general internists associated with patient satisfaction?. Journal of General Internal Medicine, 15(2), 122-128.

Hidayat, A. A. (2014). Metodologi Penelitian Keperawatan dan Teknik Analisa Data. Jakarta: Salemba Medika.

Kozier, B. (2008). Fundamentals of nursing: concepts, process and practice. Pearson Education. 
Lee, M. A., \& Yom, Y. H. (2007). A comparative study of patients' and nurses' perceptions of the quality of nursing services, satisfaction and intent to revisit the hospital: A questionnaire survey. International Journal of Nursing Studies, 44(4), 545555.

Morris, C. G., Johnson, B., Kim, S., \& Chen, F. (2008). Training family physicians in community health centers: a health workforce solution. Family Medicine, 40(4), 271.

Muninjaya, A.A.G. (2012). Manajemen Mutu Pelayanan Kesehatan. Jakarta: EGC

Nursalam. (2014). Manajemen Keperawatan: Aplikasi dalam Praktik Keperawatan Profesional. Jakarta: Salemba Medika

Satrianegara, M. F., \& Saleha, S. (2009). Buku ajar organisasi dan manajemen pelayanan kesehatan serta kebidanan. Jakarta: Salemba Medika.

Scardina, S. A. (1994). SERVQUAL: a tool for evaluating patient satisfaction with nursing care. Journal of Nursing Care Quality, 8(2), 38-46.

Supranto, J. (2011). Pengukuran Tingkat Kepuasan Pelanggan. Jakarta: Rineka Cipta

Supriyanto, S., \& Ernawati, M. (2010). Pemasaran Industri Jasa Kesehatan. Yogyakarta: Andi Offset

Teng, C. I., Dai, Y. T., Lotus Shyu, Y. I., Wong, M. K., Chu, T. L., \& Tsai, Y. H. (2009). Professional commitment, patient safety, and patient-perceived care quality. Journal of Nursing Scholarship, 41(3), 301-309.

Tjiptono, F. (2009). Prinsip-prinsip Total Quality Service. Yogyakarta: ANDI

Tribowo, C. (2013). Manajemen Pelayanan Keperawatan di Rumah Sakit. Jakarta: Trans Info Media

Tseng, M. L. (2009). A causal and effect decision making model of service quality expectation using grey-fuzzy DEMATEL approach. Expert Systems with Applications, 36(4), 7738-7748.

Tzeng, H. M., Ketefian, S., \& Redman, R. W. (2002). Relationship of nurses' assessment of organizational culture, job satisfaction, and patient satisfaction with nursing care. International Journal of Nursing Studies, 39(1), 79-84.

World Health Organization. (2009). Global standards for the initial education of professional nurses and midwives (No. WHO/HRH/HPN/08.6). Geneva: World Health Organization.

Zarei, A., Arab, M., Froushani, A. R., Rashidian, A., \& Tabatabaei, S. M. G. (2012). Service quality of private hospitals: The Iranian Patients' perspective. BMC Health Services Research, 12(1), 31.

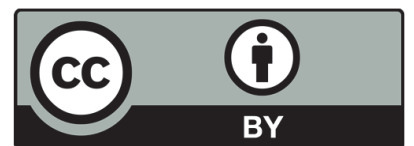

(C) 2020 by the authors; licensee Growing Science, Canada. This is an open access article distributed under the terms and conditions of the Creative Commons Attribution (CC-BY) license (http://creativecommons.org/licenses/by/4.0/). 